\title{
DNA 機能の光制御
}

浅沼浩之

天然の DNA は AGCT 4つのヌク・レオチドを構成単位 とする高分子であり, 生物学的には遺伝情報のキャリヤー としての機能をむつ。一方で DNA は相補鎖と自発的に二 重鎖を形成するという超分子としての機能む併せむってお り，生物学のみならず化学あるいは物理・情報に至る幅広 い分野にとって鬼力的な研究対象である。筆者らは, DNA がもつ多様な機能の可逆的な光制御を目指し，アゾ ベンゼンなどの “光スイッチ”の DNA への導入を行って いる。

\section{二重鎖の形成と解離の光制御}

DNA の機能発現には，二重鎖の形成と解離が関与して いる場合が多い。したがって, 二重鎖の形成と解離が特定 波長の光照射のみで制御できれば，DNA のさまざまな機 能の光スイッチングが期待できる。実際, 代表的な光応答 性分子であるアゾベンゼンを DNA の側鎖にリンカーを介 して導入することで，図 1 に示すような DNA 二重鎖の形 成と解離の光制御を実現することができた1)，2。たとえば， 6-mer の DNA にアゾベンゼンを導入した 5'-CGAXGTC$3^{\prime}(\mathrm{X}=$ 図 1 左のアゾベンゼン残基) にその相補鎖 (3'GCTCAG-5') と八イブリダイズさせると，アゾベンゼンが trans-体の場合には融解温度 $\left(T_{\mathrm{m}}\right)$ が $37.7^{\circ} \mathrm{C}$ なのに対し, cis-体では $14.4^{\circ} \mathrm{C}$ と, 実に $25^{\circ} \mathrm{C}$ 近い $T_{\mathrm{m}}$ の差が観察され る。温度を一定にしてUV・可視光照射を交互に行うと， 二重鎖の解離と形成による $260 \mathrm{~nm}$ の吸光度の増減が交 互に起きることから，pH，イオン強度，温度などの外部要 因を一切变化させず, 光照射のみで二重鎖の形成と解離を 自在に制御できる。この現象は，光照射に伴うアゾベンゼ

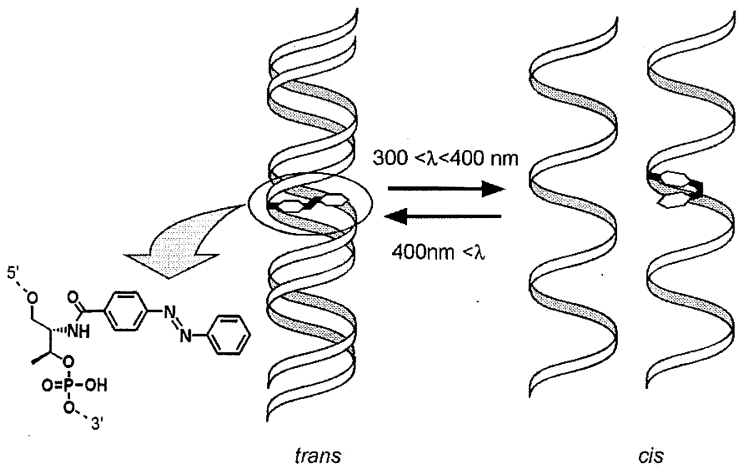

図 1 アゾベンゼンの異性化による二重鎖の形成と解離の 光制御
ンの構造異性化に基づいており，アゾベンゼンが平面構造 の trans-体の場合には，隣接する塩基対間にインターカ レートすることでスタッキング相互作用により二重鎖が安 定化する。一方, UV 光を照射して非平面構造の cis-体に 異性化すると，今度は立体障害により二重鎖を不安定化す る。このようなハイブリダイゼーションの光制御は，三重 鎖または DNA/RNA二重鎖でも可能であり，これらをア ンチセンスやアンチジーン法に応用することで，遺伝子発 現の光制御が期待できる。

\section{光応答性 DNA を用いた転写反応の光制御}

アゾベンゼンの構造異性化によって，DNA への酵素な どタンパク質の結合を直接制御することも可能である。た とえば，T7-RNA ポリメラーゼは，プロモーターと呼ばれ る 17 塩基より構成される特別な配列に結合することで転 写反応を開始する。したがって, プロモーターへのポリメ ラーゼの結合が光照射により制御できれば，転写反応の光 制御が可能となる。筆者らは T7-プロモーターにアゾベン ゼンを導入したところ，T7-RNAポリメラーゼによる転写 反応が UV 光拉よび可視光照射によって非常に効率よく 光制御できることを見いだしている3)。T7-RNA ポリメ ラーゼは in vitroでの翻訳システムがすでに確立してお り，この光スイッチングプロモーターの後に有用なタンパ ク質をコードしている遺伝子を導入すれば，in vitro での 遺伝子発現の光制御が可能になる。

以上のようにアゾベンゼンを導入することで，DNA 機 能の光スイッチングが可能なことを示した。この光応答性 DNA は，遺伝子発現の光制御のみならず，DNA コン ピューターの分子アドレッシングなど，さまざまな機能の 光制御への応用が期待できる。

\section{文 献}

1) H. Asanuma, T. Takarada, T. Yoshida, X. Liang, and M. Komiyama: Angew. Chem. Int. Ed. Engl., 40, 2671 (2001)

2) X. Liang, H. Asanuma, and M. Komiyama: J. Am. Chem Soc., 124, 1877 (2002)

3) H. Asanuma, D. Tamaru, A. Yamazawa, M. Liu, and M. Komiyama: CHEMBIOCHEM, 3, 786 (2002)

ASANUMA, Hiroyuki 東京大学先端科学技術研究セン夕ー・助教授, 工博. 専門は高分子化学, 光化学, 核酸有機化学. Photo-regulation of DNA Function 